\title{
Interpersonal Trust and Participation in Party Politics in Korea: A Generational Approach'
}

\author{
JiN Min CHING,

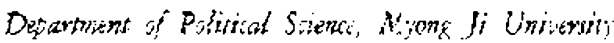

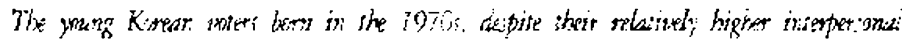

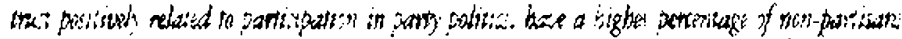

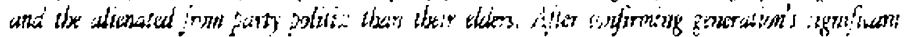

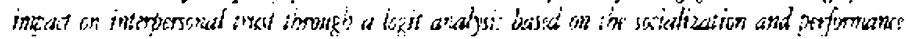

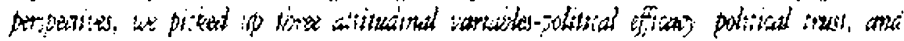

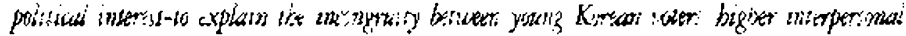

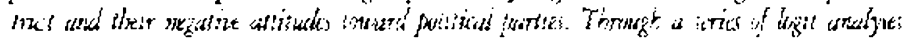

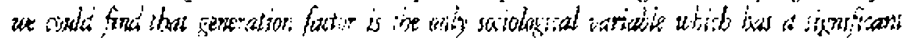

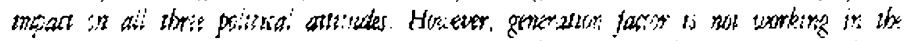

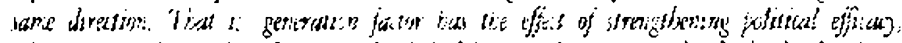

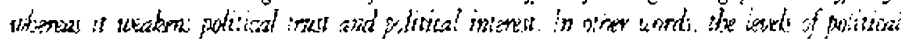

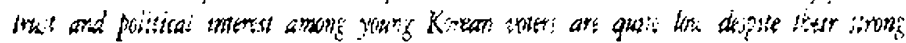

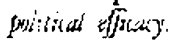

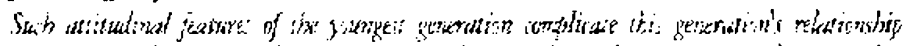

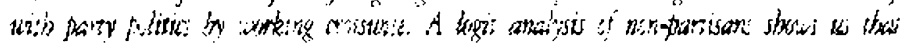

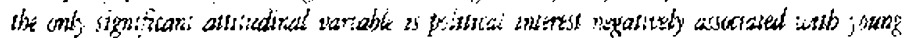

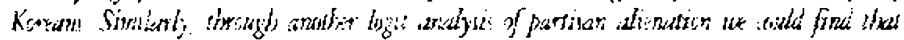

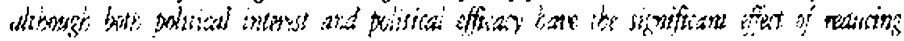

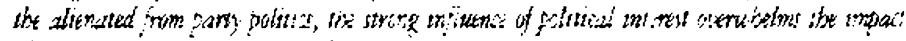

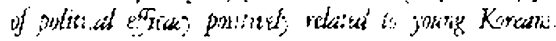

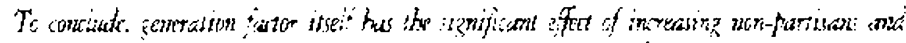

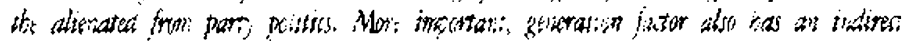

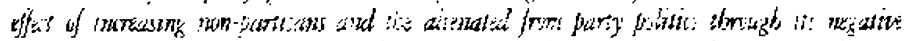

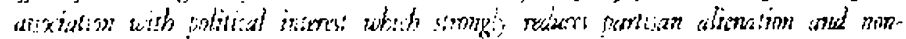

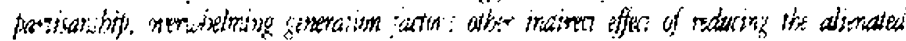

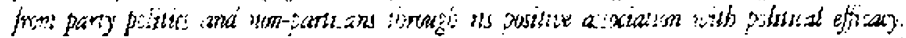

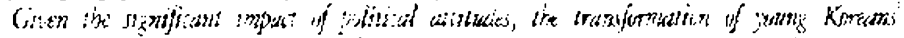

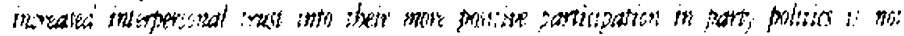

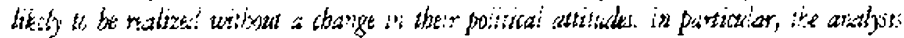

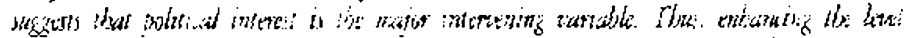

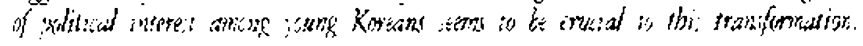

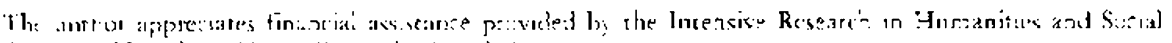

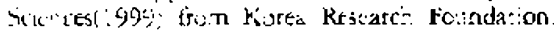

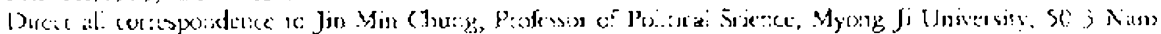

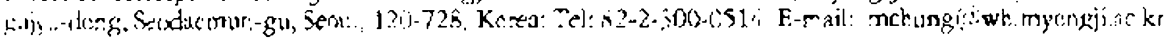




\section{INTRODLCTION}

I $\mathrm{n}$ ary mearingful domoceacy, the inerests and wishes of different menthers of sociery shonld the articulated and represerere rhrough organize? political groups, and politisal party is the most important organization mobilizing pelitical participation of citzens. In fart, a large number of citizers in most democracies participate voluntarily in parcy politics anc hare a cersain degree of psychologica attachment to major political partics. Such an active and voluatary public oarticiparion in party po.trics is an maportare fcature which cistiagushes a working vemocracy from an althoritarian political system. Thus, $x$ is irceic that mose and mere voters an democracizing Kotea

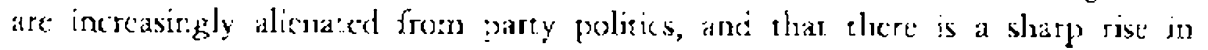

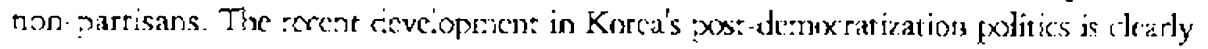
somerhing to be worried sholt since citizens active participarion in parry politics is necessary for a healihy denocracy.

More rorrsome is that non-partisans and the a'ienatec from party politics are concentrated heavily among your.e vorers, whose political attioudes rine fueure of a riusem Korean democracy depends on In terms ci interpersunal :rust, however, young Kurean votes arc knowa to liave a lighor trast level than their elders. Acourding to

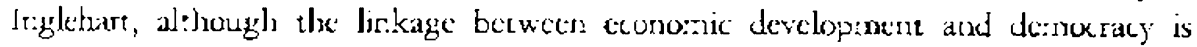

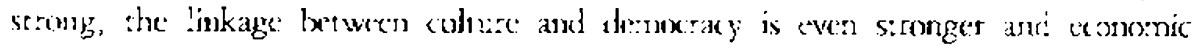

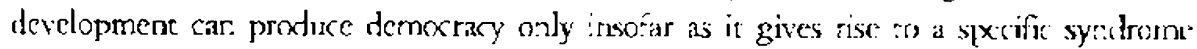
vf r:tural changes $(1097,105)$. Ir partic:iar, Ingletast emphosizes that a high level of interpersonal inse, anong with :olerance ard prostmaterial:st values, is condirive to democracy by activating participation in democratic institutions including politucal parties. In short, a'thclagh irsteased interpersoral rust among youry Koreans is a good sign for consoliciatirg Korean democracy, the rise in interpersonal trust among ycumb Kareans does nor help encourage their parcoipation in Kurean party politics.

The aim of this study is to answer the ylestiva el wisy young Korcans inereased

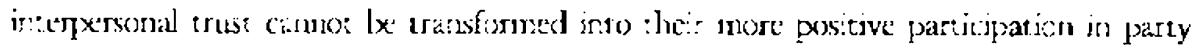

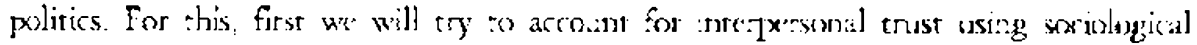
viriabics including generation and evaluatior. variables surc is public cvaluation of goverament's pcitical and foonomic achievements. Then we will turn to some political attitudes which could work as a barsier to or a cacalyst for ine trarsformation of increasec incerpersenal trise into active particifation in parry politics, and try to explan kow generational factor, a ong with othe: sociological and eva uation factors is lnked to these political attisudes. Final.y, ihts study will accourt for the mincease in non pattisaus and the alienated from party pelitis lising scciological, cvaluation, ard atric dinal Eactors, again focusing on: penerational :actos.

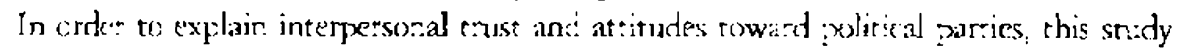
is fressec on routually distinguishable pe:erations producer' by the rapid change in Korean sociery. Gene:ational theoriss emphasizing the impact of early sociailization during one's Somative years commonly bxlieve ti:at generational effects wi.l be more salient 
whe: a soxicty (henges rapidly so that variods colorts come of age under divergene conditions (Wandieim 1952; Hyman 1959; Ryder 1965; Lanbest 19?2; Abranson 1975; Fanagan 1987; Abrarson and Ir:glehart 1992). Korcan sxicty since the enci ot the Korean War has undergone a severe, somerimes traumaric, scral disocation, affecting almos: every segment of tie society, and the speer of social shange has been further aczelerated since fuil-fledged economic development was se: in motion beginnirg in the early 1560). Thus, the historial circumstances whith various age cuhcrts we:s exposed is in their critical formative years are quite different inceed. As a result, it is cur belict that Korcan socity satisfies the conditions for maxing the gencrational afproact. a mearang:ul one manayemg Korean values a:ud policica' trilaviers.'

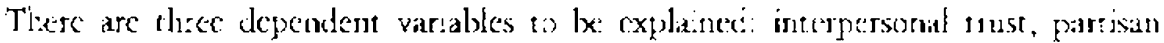
support, and partisan crienzation. Fach dejendent variable has wo catcgor:es: whethe: er cot one believes that people ase rustworthy; whether or not one has a policical party to support; and whetier or cot one has a pantisan orientation. Regarding purtisan orientation. if one can place cneself on the specinur. between government and cpposition part: se consicer that he or she has a jartisan orientation. On the othe: r.and, if one is no: incerestec in plaing onesel on the government-cppssition party

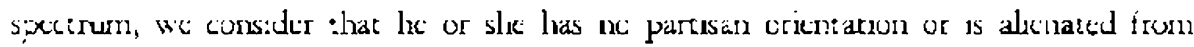
party polites. Theec otler variables are used as both deperedent ard independent

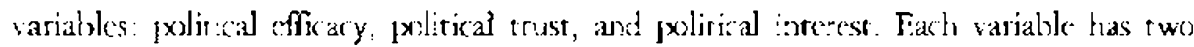
caregories: herher or not one agrees that people like me don't have any say axout whar the government does; whetice ar not one aprees that the government is pretry muciz nu for the benefit of a few peop.e regardless of puislic opinion; and whethe: cr not one has poistical ciscussicn.

In orcier :o explain the variation in dependent variables, we have seven indexendent sarrables: four sociolog:cal var:ables ralueing gender, incorxe, generation, and region, along with thec variables evaluating pelitical perionsanes, ational teconony, and

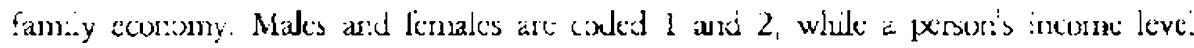

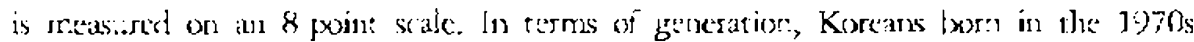
ate couted 1 and Kormen loorn txefore 1970 are soced 0 . We give !, 2, and 3 to acsicients a Yongnam, Jingbu the remairder of the nation), and Honam acgions respertively. We used a 3-poin: scale for three variables evaluacing national and farnily economic concitions and the incumixen: presicient's performance.

'The cara used here were supplied by the sejcng Insriture which conducted a survey on public consciousness ir. Kceea. The survey following the stratified random sampling method was conductec in la:e Narch and early April of 19 ys and the survey's sample size was 1,800 . Given thit an deperdent variables in this study are dicinotencus, a series of logistic regression analyses is comployed as a rajor methor: of analysis

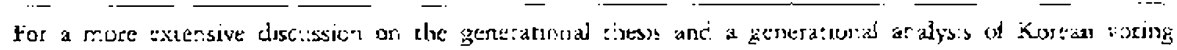

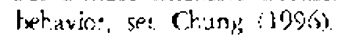




\section{INTERPERSONAL TRUST IN KOREA}

Many theorisrs lecteve that incer:xema! rrust is required for the demuxratic rules of the game to function by enabling the large-scale roxupraticn between strangers that is essential to a successfil ciemoctacy. Almond and Verbe (1963) argined that a sense of interpersonal crust is a prereouisize for et.ective democracy because tnust is necessisy for the formation of secondary associanions which is crusial to active politica. par-

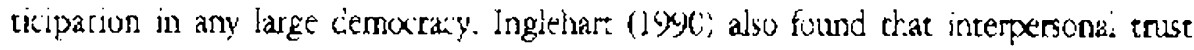
ard reaced chlural oricrations are strongly lirsed with stable democracy. Ir. a sirniar

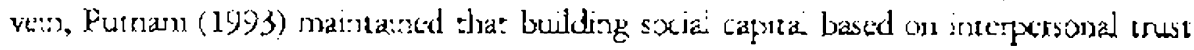

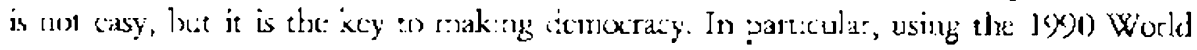

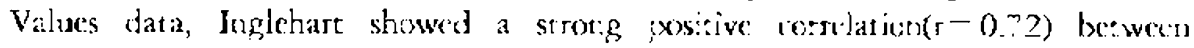

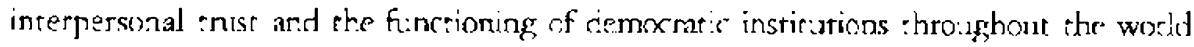
(1997, 1:3) ? In: short, a cult:ure of interpersoral :rust nakes possible exrensive netwotks of volintany associations which are essential to the centir.uolis futartionizgs. of successful dem.xracy.

When individuals participate in polincal institu:ions slich as polirical parties interpersonal trust plays an impozant role. Ihus is becazist a stable pary structure can come

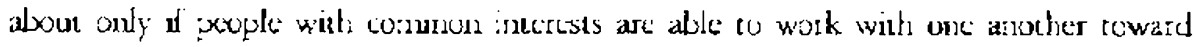
a com:ano end ard this ability rests, in tae sod. on soenal capial based on interpeisonal

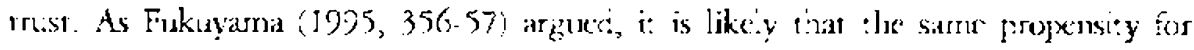
spentaneous sociability, necessary for bi:ldirg curasle buinesses, is also indispensatole for putring, topgether effective political orgarzations suca as political parries. In defaidt of rea. political partes, poitica! groupings oreen come to ize hased on changeable persoralites or patron-cient relationships. ... a pa:ror-client relationship, the need for interpersonal irust coulc no: be strong because, as Putnam $(1993,75)$ mentioned, clients of the same patro: have nothng to stake againse mutzal defection and notheng to tear from mu:dal aliciation. Asc, cliceses of the seme patron have no occasion to

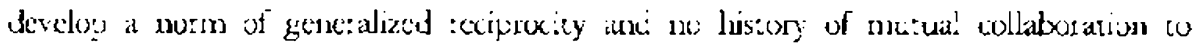
dasv ans. As a conseguence in:erpersonal trosi is no: likely to lo encouraged and

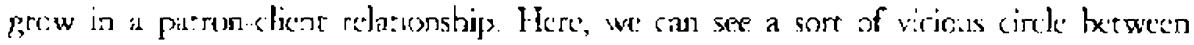
the lack of interpersona! trust and poitical grousings based on patron-cisent relationships, which in aurs. hinders the scuelopment of an effertive political pary.

Onc inceres:ing fact rega:ding iaterpersona. trist in Korea is that among threc postwat geneations, the youngest generation burn :n the 1970 s shows the highes: level of interpersonal irust as shown in lable :.

'The high levei of encerperso::al :rusi anong young Koreans is also reported isy

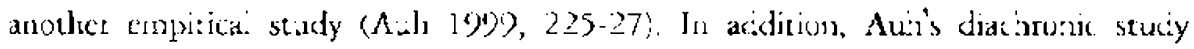
shows that the level of srust anomg young Koreans has teen exatiy enhaned over

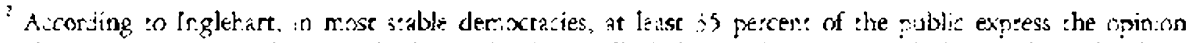

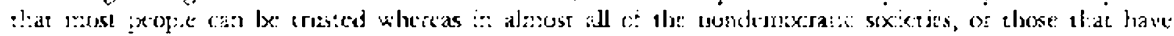

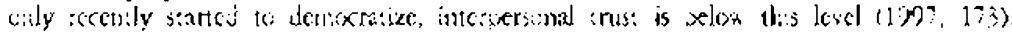




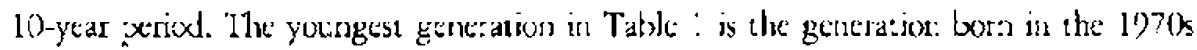
and growing up afere the 1987 Denocratization Uprisirg. During the youngest genceation's formative year the Korean economy contirure to grow, joiring an the cconomically advanced group of naticns as symbolized by Korea's admissicn into the OECD in 1996. In other words, these young Koreans have grown up in an economically prospercus env:conment, which leads to a rise in in:erpersonal trist alorg with tolerance atd postmaterialist values. Ingletant shcwed that high interpersoral trust ges along with reacively high! levels of eccnumic developmen $(r=0.53)(1900,36)$.

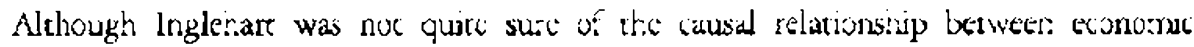
developrant: and inctoxsona' 1 rist, $x$ suggested that ecoumic development leads

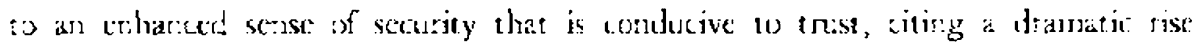
in interpersonal ense :n West Germany and Italy. In fac: it is interesting that ir. the two countries a dramatir rise in inte-persoral must rook place after a periad of rapic eronomic recovery.

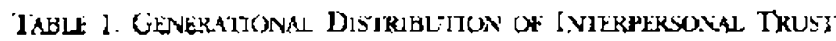

\begin{tabular}{|c|c|c|}
\hline Generation: & Interpersonal Trist & interpersona Distrust \\
\hline $1950 \mathrm{~s}$ & 47 & 53 \\
\hline $1 x^{\prime} \mathrm{s}$ & $3 ?$ & 43 \\
\hline 15):0s & 61 & 34) \\
\hline
\end{tabular}

Note: Enties ace the rescertage of espenden:s.

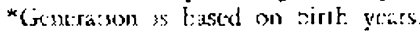

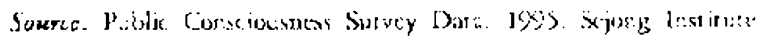

In short, internersona. trust is a sort of basis ior voluntay partizipation in political parties, and Kerea's youngest generation shon's the highest leve. of interpersonal t.ust. Honever, the youngest generations attitude toward political parties is more negative cerupased to olde: Korears, as reflecese in this geveration's highe! percentagu of nou-pantsaus and the alieranced from pary politics in alsio 2.

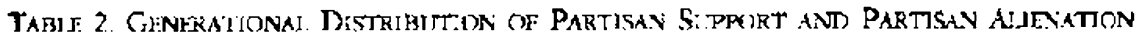

\begin{tabular}{|c|c|c|c|c|}
\hline \multirow{2}{*}{ Genemation } & \multicolumn{2}{|c|}{ Pamisan Orientaurn } & \multicolumn{2}{|c|}{ Parisas: Support } \\
\hline & Uriented & Alienated & Part:san & Non-Partican \\
\hline $2 r E-1 y \bar{l}$ & $86:$ & 14 & 25 & is \\
\hline 19: $0_{s}$ & $\%$ & 21 & -6 & $8:$ \\
\hline
\end{tabular}

Vote fin:ies ase the perce:ntage of respondenss.

Srearce: Pablic Sorsciulonts: Surfey Jara. 15i5. Sojorg lnstitz:e.

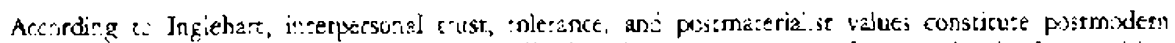

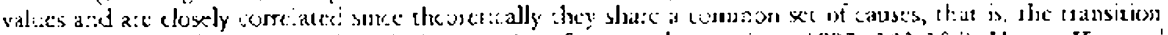

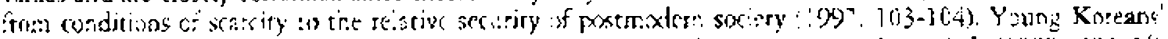

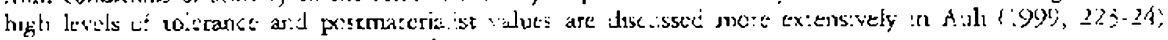

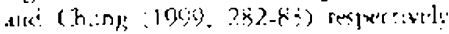


The primary rescarch question of this study, as mestimed earlier, is why the itkongruity between the youngest generat:on's higher inetpersonal trust and motc negative attitude toward political parties akes place. The first step is to explain interpersonal trust in Korea. In crder to analyze interpersonal crust in Korea, this study adopes the socialization and performance perspectives discussed in the study by Mishle: and Rose (1997, 434), which analyzed popular trust in post-Conamunise Europe. The socialization perspective err:phasizes the prirracy of early life or formarive experiences, whereas the verformance perspecrive emphasizes more recent and cor:remporary exporiences. 'Ihe soc:alization perspectsve is related :0 long-term, mo:e cnduring cultural values. $O:$ athe other hand, the pertornance perspective is associated with snort term evaduatons of governenerie's politital and ecoromic achievements, whicl cou'd easily fuctuate. Ank we believe tha: botl early life soxalization experiences anc contemporary performanre evalua:ions could influence levels of interparsonal trist.

Based or, the two perspectives, differetces in interpersonal trust are conceived as corsecuences of social backgrounci chatacteristics retlecting ons's position in the socioeconomic structire or sxiological varables, evaldarions of politica' pertormance of jucuntxent office-jokiers or day-to-ciay operations of government, ar:d evaluations of national and fanily conomic conditions. Te accoun: for the level of interpersciral crest we used tiree explanatory muciels. llke tirst awe inciule sociological varjables and

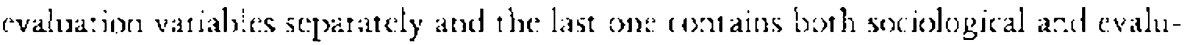
ation variables.

The first model ircludes sour sociological variablesugender, income, generarion, anc. region-to expla:n interpersonal cruse, but only the generation factor bas a significant impact on interpersonal rust, as stow: in Table 3 . in the seco.d mocel using only three evaluation variabes-evaluations of politica. performance, national eccromy, and family ecchomy-only the evaluation of cne's farrily ecomomic concions ur:as out to iave a siguticaril anpect on interpersonal trust. In terrss ef explanatury powe twe cannor find ary sabs:antal difference :xeween the two moxels.

When taree evaluation varialies are used along with four secologica. variables in the therd model, the medel's ex:lanarory newer is sonowhar increased. Here apai:1, oriy one evaluaton varable, tiat is, the evaluation of one's family economic conditons, has a significant impact on inter:xersona.' trust, and genetation faccor conainuss to se significant. From the logi: model we car. also cuaw an odcs ratio berween wo generarions. In te:ms of adcis ratio, young Ko:ears born in :he -970 s are :.3 times more jke'y to believe that people are tnistwurthy tran Koreans bern xefore $19 \% 0$.

l:1 sun, both early life sucializa: on experiences and contemporary performance evaluations abrost equally influence matersona trust. Aromg sexiolegical variajles, oriay

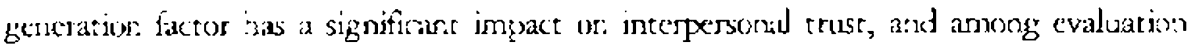
virables, only the evaluation of enc's family eronomir condirions significantly influences interpersonil : nist. 


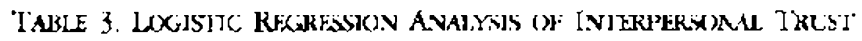

\begin{tabular}{|c|c|c|c|}
\hline & Model: & Moxkel fi! & Mrodel If \\
\hline Erender & -0.01 & & 0.0 \\
\hline licome & 0.03 & & 0.05 \\
\hline Gereration & $0.06^{\circ}$ & & $\varepsilon .16^{\circ}$ \\
\hline Ragion. & 005 & & 0.0 \\
\hline P'sli:ıal P'ertombinue & & Dos & 0.05 \\
\hline Nationa Fcomomy & & 0.02 & $0.0:$ \\
\hline Family Fronnmy & & $0.077^{7 *}$ & $00^{-}$ \\
\hline - Zlng 1. & $1:\left(x^{\circ}\right.$ & $15.62^{\circ}$ & $26,09^{\circ}$ \\
\hline Concoriant & $5: 9 \%$ & 50.856 & $56.0 \%$ \\
\hline $\mathrm{V}$ & 1,300 & 1.870 & $i, 8(0)$ \\
\hline
\end{tabular}

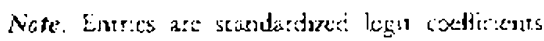

$\because p<0<* \cdots<01$

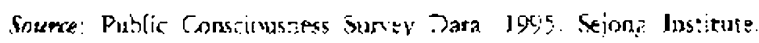

\section{II1. POLITICAL A'TITIUDES AND PARTICIPATION IN PARTY POLITICS}

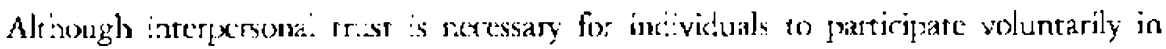
political partics, ohv:ousiy irterpersonal srust itself ss ror enough to artivate public particjpation in party politics, as showr in the sase of young voters of democ:atizing Korea. Here we focus co three pcitically more rslevant atrituces, that is political fffrcacy, political crus:, and polirica interest.

Politica! efticary is a belief that one car, influence the political process or have an effect on decisions mace in t:e pchitical systern, whereas political ansi céers to the

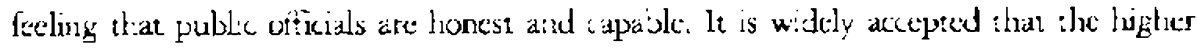

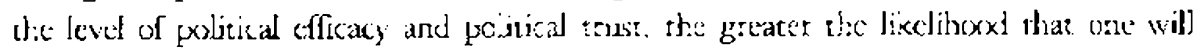

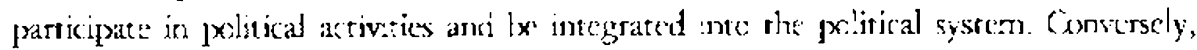

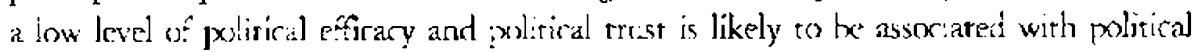
apathy or alicnation. Arothe: general proposition regarding peicical participation is chat the roore stimu': atour politics a person receives, the geracer the likelihood that he o. she will partic:pate in politics. Persons wion are interested in politics expose thernst'ves more to political stimili than those who are not so interested. In other words,

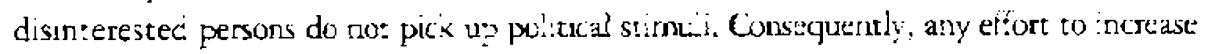
pubsic partic:pation in political accivitics raust fird scme way te maintain iaxe merest ú ciinacis.

Since politicial efficacy, polirical trust, and poititical icterest have long been corsidesed the frimary artirudes which link cirizers to demeratis institutions, onc logical roroliary is that these political articudes are closcly relaced to subic parricipation in party politics. In cther nords, if people iave high levels of political efficacy, political tnist, 
ard political interest, we coule expect a vigorous participation in party politics. As in the analysis of interpreme. 1rust, we lised sociological and evaluarion variables

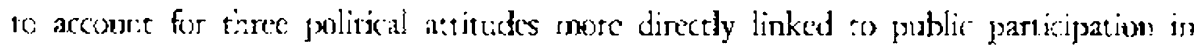
party poltics. First, a mordel including for: soxiological variables was $1250 \mathrm{~d}$ :o acrount for pxlitical efficacy. As demons:rated in Table 4 , he:e again 1me's generarion has the roost sign'ficant izpact, althougin the inf.uerces of yender and -egion are also sigrificint. Wher we acded thee evaluation variables ir. the second model, we could not find ary significa:t impact of evaluerion variables anc the model's explanatory popier ras improved uny sightly. More important, huwever, the gereration: factor continucs to have the mos: slguffcant pesitive impate en political cticary in the second rundel.

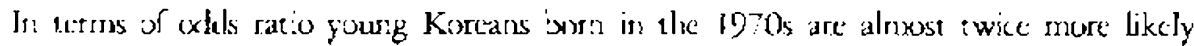
10 beleve that they can inflexice the poslie cal proxess than Koreans born lefore 1970.

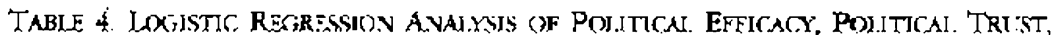
AND PO:MTALL INTIEREST

\begin{tabular}{|c|c|c|c|c|c|c|}
\hline & \multicolumn{2}{|c|}{ Póitical Efficacy } & \multicolumn{2}{|c|}{ Pedivical Trust } & \multicolumn{2}{|c|}{ Political Intexst } \\
\hline & Maxdel i & Noxtel II & Mrxtel I & Mxkel ị & Mexke-1 I & Mixix! I! \\
\hline Gromker & $0.08^{-4 x}$ & $\cos 8^{\circ}$ & 0.25 & cios & 0.28 & $n 2 s^{\circ}$ \\
\hline Inconre & 0.03 & 3.03 & -0.05 & $-i . x^{\prime}$ & $0.17^{*}$ & 0.12 \\
\hline Geseration & $0.24^{\prime *}$ & $0.14^{\circ}$ & -0.05 & $-0.26^{\circ}$ & $.0 .0^{\circ *}$ & -0.08 \\
\hline Regior. & $0 .(x)^{* *}$ & $2.08^{\circ}$ & $.0 . .1$ & ciol & $-00^{\circ}$ & $-0.35^{\circ}$ \\
\hline Politicil Performance & & 0.05 & & $6.08^{\circ}$ & & $-C . D 0^{\circ}$ \\
\hline Nationel Fomus:y & & $20 ?$ & & $(0) ?$ & & c.01 \\
\hline Fansily Fronorry & & 203 & & cos & & c. 04 \\
\hline 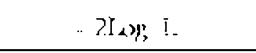 & $99.90^{\circ "}$ & $53.88^{\circ}$ & $11.65^{\circ}$ & $2187^{\circ "}$ & $135.83^{\circ "}$ & $142.07^{\circ}$ \\
\hline Camisurcint & $57.6 \%$ & $503 \%$ & $52-20$ & $5 s \%$ & Gitom & $65.6 \%$ \\
\hline $\mathrm{N}$ & $1, S \times 0$ & 1,500 & $1,8 \mathrm{~m}$ & $1, \sin$ & $\therefore 800$ & 1.500 \\
\hline
\end{tabular}

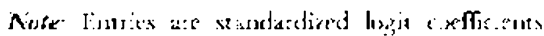
$p<0<+0<$ (i)

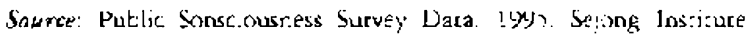

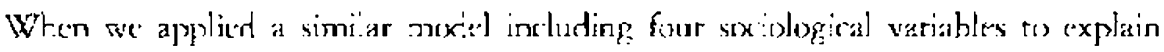
political tnest, grencration. factor is the orly variable wirc a significant impast on political trust. In the second model adding three evaluarion variables to soc:ologica variables, only the evaluation of political performance turned ou: to $\boldsymbol{x}$ significant. However, the increase in the explanatory prower of the second mocel is not that impressive. Again, thes impact of generation cont:nues to be significan: in the second rodel, but the gencration facturs mpact co political :rws, unlike its impact on political efficacy: is

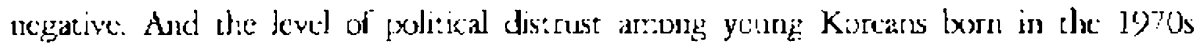

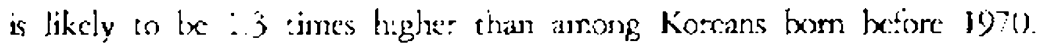

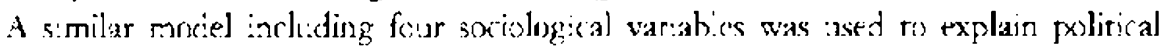
interest. and all four variables curn out ta te sir;ifican: As stown in Table 4 , the 
ir::luences of gerder, income, and geneation are significant at the (:01 level, whereas regivis's mpace on political inserest is significant at be 0.05 level. When theec

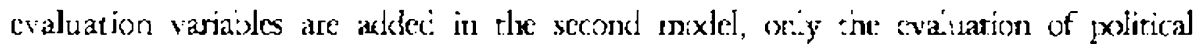
performance has an impart significant at the 0.05 level. Here again, the explanarory power of the second moxiel is arly slightly improved, and the gereration factor's impacr on political interest is aggative. I: terms of adds ratio young Koreans born in the 1970s are 1.4 times less likely to be interested in polit:cs thar. Koreans born betore 1970 .

To summarize, generation tactor is tice only sociological varjajle which has a significant irupact on all threc politcal ateitudes, "The logut analyses o: polincal attutudis

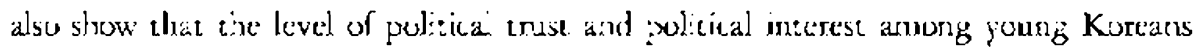
born :n the 1970 is lower sespite tacis stronger politisal efficar y, conyared to Koreans bon before $19^{-} 0$. Among cvaluation varial'es coly the evaluation of political per formance has some immact or political mise and political interest. Orherwise, the irfluences of evaluation variabios are a'most negl:gibie, contributing oniy madestly to iraprcving the radel's explanatory porer. Thiss, we can concluce that the differences ir. major poicical artitudes residted mostly from one's position in the socioeconomic stucture rathe: than contemporary perfomarce evaluations, and that among sociological variables, the generation lactor's impac: or poitical attitudes is most salient.

\section{AI.IENATION FROM PARTY POIITICS AND INCREASE IN NON- PARTISANS.}

In the post-3987 Democratizarion period, Korean voters' alienation from party polirics has deepener. As a result, ron-parisans who do not s'upport any poidrical party have coninued to iacrease. Aciording to So, the pe:centage of non-partisans among Korean voters was $22.7 \%$ in the $15 \% 2$ presidential electson and sharply zose to $40.8 \%$ in the 1995 regional and local elections $1999,404-4053$. By the time of the 1998 regional anc lecal elccior:s, non-par:isans anong Korcar: vo:ers grew to $52.1 \%$. As a mater of fiace, we efrer hear that at least haf of the Korean cectorase texlay is mon partisan. In particular, the more serisis alieration fam pary : xolisics among young werss is cleatly ane of the majur prothlems in the consolidarion process of a nasceat Korkan democracy.

To accour: for the inctease of zon-zarisars and the alienated frors. party politics and non-partisa.s among Korean voters, we appliec three mociels using sociological variaisles or.ly, sociological varisbles comincd with evaluation variables, and scciological varables added to at:itudinal variables, as illustrated in mabie 5.

When we used the tirs: mode. including four scsiological variables i: order to explain parrisan orientation, all fora variables including generation rurned out to be signif:sart. In the sccond moxel adding, three evaluation variatices ro the sociological variables, we could find ary evaluation variale with sannifican impact on partisan 
orientation. However, whon we added three attitudinal vaniables in the third moxdel. polinical ineerest and political efficacy turaed out to bave a sigrificant inpsact m partisan orientation. We could also find that the contributiot: of atitudinal variables to expaining partisan cripntation was greater than that of evaluation variailes, as demorstrared in Table 5. Generat:on factor influences partisan crientation negarively, which means the increase of the alienated from party politics among young Kareans. In fact in terms of adds ratio yourg Koreans bor: in the 1970 ose 1.6 times more likely to be alienated from party politics than Koreans worr. betore 1970 . an ocher words. many young Koreans are nor irterestec in placing themse.ves on the government-opposition parry spectrum). 'They might resist adapling to the wirols palanetse of the present Korean party system, probably searching for a new alcerrative. This tendency of many young Korears, wi

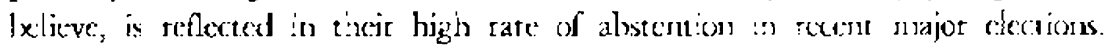

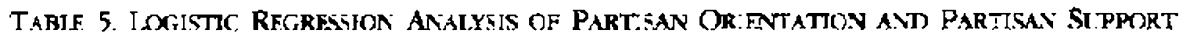

\begin{tabular}{|c|c|c|c|c|c|c|}
\hline & \multicolumn{3}{|c|}{ Paruisan OTikrataions } & \multicolumn{3}{|c|}{ Partisan Suppors } \\
\hline & Moxtel 1 & Mociel Il & Moxde: $\Perp$ & Moxtel & Mexke! II & Model III \\
\hline Grorder & $-0.1 \%$ & $-0 .: 7$ & $.0 .11^{-}$ & $-0.09^{--}$ & $-0.0)^{\circ}$ & .005 \\
\hline lureme & $0.18^{\circ "}$ & $0: 7$ & $0.15 *$ & 0.01 & 001 & $0.8:$ \\
\hline Gencration & $2.11^{\prime *}$ & $0.1^{\prime \prime}$ & $0.12^{*}$ & $5.11^{\circ "}$ & $0.11^{* *}$ & $0.3 \%$ \\
\hline Regiona & $0.11^{\circ}$ & $0.11^{*}$ & $0.12^{* *}$ & $0.16^{\prime \prime}$ & $0.16^{\circ}$ & $0: 6$ \\
\hline Political Penformasse & & 0.55 & & & $0.2 A$ & \\
\hline Varional Econom: & & $0 . .2$ & & & -0.01 & \\
\hline Far:ily Euxuany & & 0.3 & & & 0.03 & \\
\hline Peiditia Trust & & & 0.03 & & & 001 \\
\hline Polinical Interest & & & $0.2 .1^{* *}$ & & & $0.17^{* *}$ \\
\hline Pol.sical Efficacy & & & $0.30^{\circ}$ & & & 0.02 \\
\hline . $2 \operatorname{Lng} \mathrm{L}$ & $60.49^{\circ}$ & $66: 3^{*}$ & $10161^{\circ}$ & $44.86^{\circ}$ & $47.62^{\circ}$ & 71.06 \\
\hline Concordant & $63.30 \%$ & 65.280 & $68.4 \%$ & $578 \%$ & $60.5 \%$ & $62.5 \%$ \\
\hline $\mathrm{v}$ & 1800 & $1, \mathbb{P}(0)$ & $: 800$ & 1,800 & 1,800 & 1.800 \\
\hline
\end{tabular}

Note: Entres are standirdize: logit cixfficients.

$* p<.05, * * p<.01$

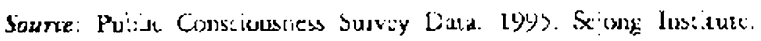

A similar mocid including four sociological variables was used to explain partican slipport. As showin :n Table 5, all of the sxiolog:cal variables excep: for income level had a significant impac: or. partisan support. When three evaluation variables were acdec in the seconc model, like in the analys:s of partisan orientar:on, we could not find any evaluation variajle wst: a significant imapact on partisan support. Atdeng three at:itudinal variabies, however, makes a difencence. Uni.je cvaluatemn varsables, politcial

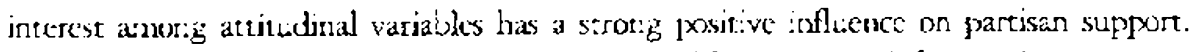
Also, the throd model includir $z^{\prime}$ atitudinal variables accourter: for partisan support betre: than the second moxed asing evaluation variables. Again, generation factor has 
a segative ingace on partisan suppore, which means the increase of non-partisans ansong young Kurzals. Ir: terms of odds ratio, the level of nor-partisans among young Korcus born in tac 1970 s is likely to :xe: 6 : imes highe: than among Koreans burn bxfore 1970.

As shown in the logit analysis si political attiturles in Table 4, young Koreans born in the 1970s display very strong political efficacy whereas their political interest anc political irust are dismally low. Such conflicting poitical atticudes of Koreans born ir. the 1970s complicated our expectations regarding young Koreans paricization in parry polirics, becalise strong poilical eflicacy ustally encouages an active participation in party politics, while low political interese zogether with low poitical trust discourages it.

The logy: analysis of partisan orikatation and partisan suppert in Tabe 5 gives us an answer to this complisated matter. Alrhough both political interest and pelitical efficary have a strong positive effect on partisan orientarion by reducing the alienated from parcy polir:cs, the effect of political inierest is muct. st-onger than that of po.itical efficacy. in othe: words, in terms of reducing partisan alienation, the inf.uence of policica efficacy positively selutec to young Koreans is dwartec by the strong etfect of polisica: interest regarivey associated with young Koreans. Since young Kcrcans level of polincal intercst is lower than that ut old Korcans bo:n before $: 970$, tie stronger impan of political interest does at act: reduce partisar alienaties anong yousug Korsans born letiore 19:0s.

In terms of effect on partisan suppert, reither politica' trist nor polirica efficacy turns out to be significant. Oriy political interest has a significant xositive effect on partisan support. iy reducing nen-partisans. ln other words, tae effect political êacary prsitively l:nked to young Kcreans is almos: negligible while only the strong infiuence of poitical interest aegatively associated with yurg Koreans prevails. Therefore, the signif:cant efiect of political ircerest on partisan support cices not help reduce non-partisans arong ycung Koreáis citlic:..

\section{SUMMARY AND CONCIIISIONS}

As far as incerperomal :nust in Korea :s concemed, young Koteans born in the 1970 s shows the highest !evel, reflecting an enhancec sense of securiry la:gely cue to economic prosperity in their format:ve years. Given the positive effect of interpersonal trist cn participation in party folit:s, we could expect that young Koreans atsitude cowate political parties is less :agative cornpared to old kurears botn before 19 \% 0 . However, th:e reverse is rue and yourig Kortans have higher percentage of non partisans ard the alienater from party polis's thar older Koreans.

Afres confirming signicicart impart the gentration factor has ca incerpersonal trust th:ough a logit analysis based or socialization anc. pefformance perspectives, we pickec up thee artitudical variàles to explain the incongr uity berween young Koreans 


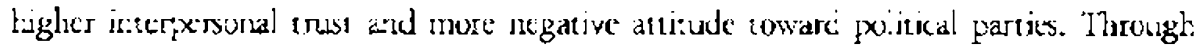
a stries of logit anayses we could find that generation is the uriy sociolugical variable which has a signnificart: impact on all three political attitudes. Inowever, generation. farter does not wo:k is the same direcrion. Thas is, the generation: factor strengthens political afficacy but weakens political trist and policica. interes:- In ocher wo:ds, the levels of politica' trist and polizical ir.erest among young Koreans born in the 1970.5 are cuite low despite thei: strong political efficacy.

Such atticudinal features of young Korans conplicate their relationship witn party politics by working cresswise. A logit analysis of aur-patrisars snopis us that the only s:ginticant attitudinal variable is political interest acganively associated with young Korcans Sirnilarly, through another logit anralysis of pareisan a.jernation, we find that

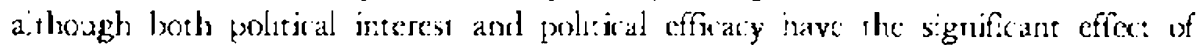
reducing, the alenared from party politics, the strong, influenee of political interest regatively associated with yoing Koreans owerwinelms the impact of polisical efficary pusitively related to young Korea:ss.

To conclide, genetation factor isself has the significant effect of increasing ron-partisans and the allenared from pary politcs. More important, generation factor aso has an ind:recs effect of incteasing nor-partisans and the alienated from party politics :hrough its negative association wilh politicai miterest wluch strongly seduces partisan alienation and nor-pa-tisans..p. This indirect negative effect of gercration factor overwhelens generacon factor's oxhes iadirect effect of seducing nom partisans and the alienated fam parry politics through its peositive association with political efficacy because pelitical interest has a mush stromper impart on parrisan oricntation and parisar. support tian paitical efîtcacy. Given the sigrificant impact of political artitudes. the transformation of young Kcreans' increasec in:erpersonal trust into their more positive participarion in party poitics is rot likely to be realizec without a change In their politica' attirudes. In yart:cular, the analysis suggests that political interes: is the najor intervenirg variable. Thus, enkancing the level ef political interest aurong

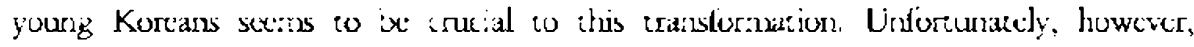
comsicteriag tha: the regionalism basece pany sys:cm with a highly persomalized party

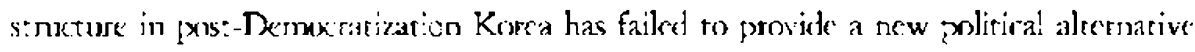
appeading to ycung Kercass, it is very linliketly to expert present party system to stimulate rhe political interest of young Koreans, whose concerns of innerest continue wh diversified as the postmateriaist uriertarion of young Koreans has ixen reirforced over time. 


\section{REFERENCES}

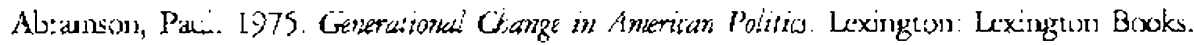

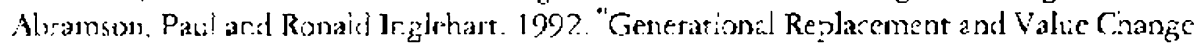
in Eight West European Jorieties." Fritith joumal if Political Science 22: 183-228.

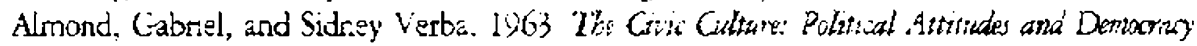
in Iiat Vatoms. Princeton: Pnnccton Linversity Fress.

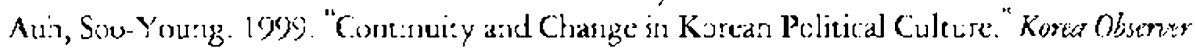
$30 \cdot 2.11 \cdot 46$

Ching, Ji: Mn. 1996. "A Grenerationa' Analyss of the 1992 Presidential Election in Korea." Korean Soridi Sirems Joumai 22: 145-64.

i99\%. "Changes in tine Political Party Enverenment of Kurca and lie Reform of Party Poliuics (Korean). Nertiunal Strategy 5: 27999.

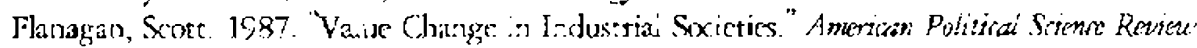
81: $130 ; \hat{j}-18$.

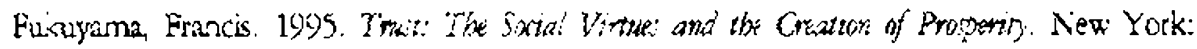
Fuce Press.

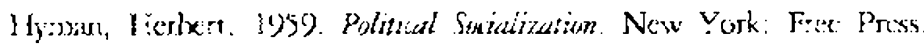

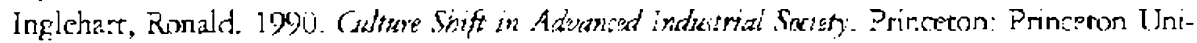
versizy. Press.

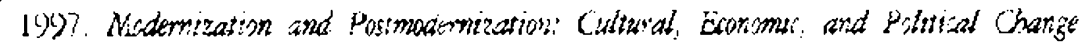
in 43 S\% iztrits. Princetcin: Princtor: U:aiversity Press.

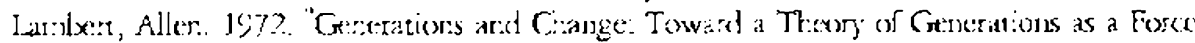

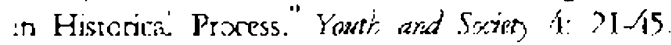

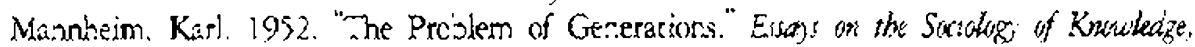
ed. 2. Kecsxemeti. NY: Oxtord Lnversiry Press.

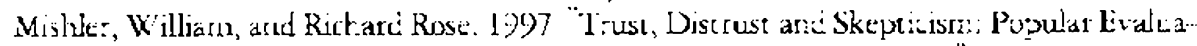

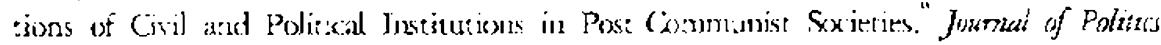
59. 118.5]

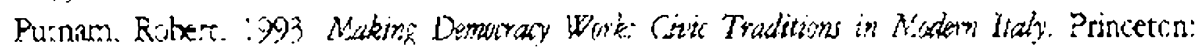
Princeten Lniversity Press.

Ryder, Nennan. 1965. "The Age Cchurt as a Concepr in :he Study o: Sondal Change."

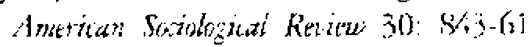

S): Sxun Chang. 1099. "An Fmoirical Analy'sis of Non-Partisans in. Korean local Fleninns(Kcrear.)" Korea' Elettinn. ed. Jurg Ein Cho. Secul: Naraar. 